\title{
Robotic surgery at ABC Medical Center: first 500 procedures experience
}

\author{
Carlos Vásquez-Lastra, ${ }^{1 *}$ Cesar Decanini-Terán, ${ }^{2}$ Antonio Maffuz-Aziz, ${ }^{3}$ Jaime Alfaro-Alfaro, ${ }^{4}$ \\ José A. Huante-Pérez, ${ }^{1}$ Enrique Wolpert-Barraza, ${ }^{5}$ Luis F. Sánchez-Marle ${ }^{5}$ and \\ Arturo Gutiérrez-Hernández ${ }^{6}$ \\ ${ }^{1}$ Urology Department; ${ }^{2}$ Department of Surgery; ${ }^{3}$ Department of Surgical Oncology; ${ }^{4}$ Gynecology Department; ${ }^{5}$ Medical Direction; ${ }^{6}$ Surgery Service \\ Line Management. Robotic Surgery Committee, Centro Médico ABC, Mexico City, Mexico
}

\begin{abstract}
Background: Robotic surgery is a technological advance that is used in multiple surgical specialties in the world. Its acceptance in various areas has been supported by comparative studies with laparoscopic surgery and open surgery. Objective: To document the robotic surgery program initial experience in a private hospital of Mexico City by analyzing its results and complications. Material and method: The first 500 robotic surgeries practiced at ABC Medical Center were included, covering a three-year period (January 2017 to December 2019). The following was documented: specialties involved, surgeries broken down by specialty and type of surgery, surgical times, complications and number of doctors involved in the initial experience. Results: Out of 500 patients, 367 (73.4 \%) were males and 133 (26.4\%) were females. The three most common surgeries were radical prostatectomy (269), hysterectomy (64) and inguinal repair (33). Average age was 58 years (range: 18 to 90 years). A total of 40 certified surgeons from five specialties performed all the procedures. Conclusions: Starting a program in a private medical center has several implications. The creation of a robotic surgery committee made up of certified robotic surgery specialists from each specialty and hospital authorities for the accreditation of guidelines for both certification and recertification of their doctors can benefit programs like ours by creating a center of excellence in robotic surgery and thus reduce complications and improve results.
\end{abstract}

KEY WORDS: Da Vinci. Robotic surgery. Initial experience. Prostatectomy. Hysterectomy.

\section{Cirugía robótica en el Centro Médico ABC: experiencia en los primeros 500 procedimientos realizados}

\section{Resumen}

Antecedentes: La cirugía robótica se utiliza en múltiples especialidades quirúrgicas a nivel mundial. Objetivo: Documentar la experiencia inicial del programa de cirugía robótica en un hospital de práctica privada. Material y método: Se incluyen las primeras 500 cirugías robóticas realizadas en el Centro Médico ABC, abarcando un periodo de tres años. Se documentan especialidades involucradas así como datos transoperatorios principales. Resultados: De 500 pacientes, 367 (73.4\%) fueron de sexo masculino y 133 (26.4\%) de sexo femenino. Las tres cirugías más realizada fueron prostatectomía radical (269), seguido de histerectomía (64) y plastia inguinal (33). Un total de 40 médicos certificados de cinco especialidades realizaron la totalidad de los procedimientos. Conclusiones: El iniciar un programa en un centro médico privado tiene diversas implicaciones. La creación de un comité de cirugía robótica integrado por médicos especialistas certificados en cirugía robótica de 
cada especialidad y autoridades del hospital para la acreditación de lineamientos tanto para la certificación como la recertificación de sus médicos puede beneficiar a programas como el nuestro por crear un centro de excelencia de cirugía robótica, disminuyendo complicaciones y mejorando resultados.

PALABRAS ClaveS: Da Vinci. Cirugía robótica. Experiencia inicial. Prostatectomía. Histerectomía.

\section{Introduction}

Robotic surgery has become the standard approach in a growing number of surgical procedures. In the world, robotic surgery programs have grown in recent years, with the robotic approach having been established as the surgery of choice in a large number of centers and adapted to various surgical specialties. ${ }^{1-3}$ Since the first robotic surgery, performed in March 1997 by Cadière, ${ }^{4}$ indications for this surgical platform have increased year after year. There are still procedures in which there may be some controversy regarding the advantage robotic surgery might have over conventional laparoscopic surgery. ${ }^{5-7}$ However, every year, the number of procedures in which robotic surgery is established as the approach of choice increases. Continuous advances and improvements in equipment, as well as the advent of new robotic platforms in the coming years after original equipment patents expire, will make robotic surgery the approach of choice in a larger number of surgical procedures.

The start of any robotic surgery program can be overwhelming due to the challenges this implies. ${ }^{8,9}$ Having medical, nursing, biomedical engineering and administrative staff in synchrony to adapt a new technology and assume their role in the new project can be a complex challenge. Although robotic surgery can have great advantages in terms of learning over laparoscopic surgery, ${ }^{10}$ creating a robotic surgery program at any medical institution implies having surgeons that are trained and continuously training, personnel who learn the operation of a completely new equipment, with different surgical steps, and administrative staff looking to make a program that is different from anything they had previously managed, grow. In addition, carrying this out in a private hospital implies having an economic model with the capacity to create a business plan with the equipment supplier and insurance companies.

As we reported in our previous publication, ${ }^{11}$ it is crucial for a robotic surgery committee made up of the different specialties involved to be established in order to jointly being able to evaluate cases, authorize procedures, and have a medical group that supports physicians who are new to this area with their experience in robotic surgery, and that justifies the use of robotic surgery before insurance companies. ${ }^{12-14}$ This way, minimizing complications and establishing filters that can guarantee an adequate development of a new program with so many medical and administrative implications has been possible..$^{15-17}$

In this publication we present the first 500 cases of robotic surgery at $A B C$ Hospital, as well as the results obtained in this part of our experience.

\section{Objective}

To evaluate the results of the first 500 robotic surgery cases at ABC Medical Center from January 2017 to December 2019, analyzing the number of certified physicians, the specialties involved, types of surgeries, surgical times and complications. In addition, to compare the results between the first 250 and the last 250 cases.

\section{Material and method}

The robotic equipment at $\mathrm{ABC}$ Hospital Observatorio Campus is the Da Vinci S surgical system (Intuitive Surgical Inc., Sunnyvale, CA). The equipment was installed in December 2016 and the first surgery was performed on January 23, 2017. From that date to December 2019, 500 robotic surgeries have been practiced.

Since the beginning of the program, a robotic surgery committee was created for the evaluation of certified doctors, issuance of credentials and follow-up of robotic surgery cases in order to control the results and projections of the program. The committee is made up of doctors from involved specialties, biomedical engineers, financial body staff and hospital authorities. All cases were scheduled to be submitted for consideration and approval by the robotic surgery committee. We analyzed all the surgeries practiced at the hospital, as well as the specialty, type of surgery, number of certified surgeons, surgical times, complications, conversions and days of hospital stay. 


\section{Results}

Within the first three years of the program, 500 robotic surgeries have been practiced at $A B C$ medical center. Out of these, 367 involved male patients $(73.4 \%)$ and 133 involved females $(26.4 \%)$, with a mean age of 58 years (range: 18 to 90 years). Table 1 shows the breakdown by age range.

Table 2 shows the breakdown of surgeries by procedure. The most commonly performed surgery was radical prostatectomy, with 269 procedures, followed by hysterectomy, inguinal repair and radical nephrectomy.

Urological surgery accounted for the majority of procedures, contributing with 346 surgeries $(69.2 \%)$, followed by gynecological procedures with $84(16.8 \%)$, general surgery with $48(9.6 \%)$, thoracic surgery with $18(3.6 \%)$, and oncological surgery with $4(0.8 \%)$.

Average days of hospital stay was 2.95 days, with a range of one to 28 days. Robot-assisted cystoprostatectomy was one of the most complex procedures that was performed, and accounted for the highest number of days of hospital stay, with an average of 11 days (range: 7 to 28). When this procedure is excluded, average number of hospital stay days drops to 2.6 days.

Average surgical time was 4 hours 35 minutes, with a range of 45 minutes to 13 hours 40 minutes.

Average bleeding for all procedures was $250 \mathrm{~mL}$, with a range of $5-3,250 \mathrm{~mL}$. Of the 500 cases, 475 did not require transfusion, and only 25 patients (5\%) received transfusions.

At the beginning of the program, we had six certified physicians with $A B C$ credentials to perform robotic surgery. Out of them, four were urologists and two were gynecologists. Over the course of the three years of the program, a total of 34 additional physicians have been certified, and currently there are 40 physicians certified by Intuitive Surgical ${ }^{\circledR}$ and licensed to practice robotic surgery in their specialty areas. The training program for surgeons' certification followed the company's global regulations. It consisted of 40 hours of simulator training, followed by 10 hours of training with surgical models, a certified course with simulator/surgical model/animal model at one of the certified centers and, finally, performance of a surgery with the support of a certified teacher endorsed by Intuitive Surgical ${ }^{\circledR}$ and the specialty in question.

The robotic surgery committee served as a qualifying body to ensure correct certification or recertification of doctors, as well as to enable standardization
Table 1. Distribution by age range

\begin{tabular}{|l|c|c|}
\hline Age range (years) & Number & $\%$ \\
\hline $18-20$ & 5 & 1 \\
\hline $21-30$ & 11 & 2.2 \\
\hline $31-40$ & 40 & 8 \\
\hline $41-50$ & 70 & 14 \\
\hline $51-60$ & 119 & 23.8 \\
\hline $61-70$ & 173 & 34.6 \\
\hline $71-80$ & 80 & 16 \\
\hline $81-90$ & 2 & 0.4 \\
\hline
\end{tabular}

Table 2. Performed surgeries

\begin{tabular}{|c|c|}
\hline \multicolumn{2}{|c|}{$\begin{array}{l}\text { First } 500 \text { cases } \\
\text { January 2017- December } 2019 \text { period }\end{array}$} \\
\hline Radical prostatectomy & 269 \\
\hline Hysterectomy & 64 \\
\hline Inguinal repair & 33 \\
\hline Radical nephrectomy & 25 \\
\hline Cystectomy & 21 \\
\hline Lobectomy lung surgery & 18 \\
\hline Myomectomy & 16 \\
\hline Partial nephrectomy & 12 \\
\hline Fundoplication & 8 \\
\hline Ureteropyelic repair & 8 \\
\hline Ureteral reimplantation & 5 \\
\hline Cholecystectomy & 5 \\
\hline Lymphadenectomy & 4 \\
\hline Oophorectomy & 4 \\
\hline Colpo-sacral suspension & 2 \\
\hline Biliodigestive derivation & 2 \\
\hline Retroperitoneal tumor & 2 \\
\hline Pancreatic surgery & 2 \\
\hline Total & 500 \\
\hline
\end{tabular}

of supplies for each one of the procedures, thus improving the economic factor.

There were 33 complications in the first 500 cases $(6.6 \%)$, with the majority being Clavien I. The 
Clavien-Dindo complication classification system is a standardized system, accepted for the reporting of surgical complications. ${ }^{18}$ This classification is shown in table 3. The distribution of complications according to Clavien-Dindo classification is shown in table 4 . The most important complications were massive bleeding (after nephrectomy), duodenal perforation (after cystoprostatectomy), intraoperative bleeding warranting conversion, and infections that warranted hospital readmission.

\section{Discussion}

Robotic surgery has become the approach of choice in a growing number of surgical procedures. ${ }^{1,3,18,19}$ The advent of new technologies, such as the Da Vinci Xi equipment, as well as announcements made by various companies regarding changes and modifications in new platforms, will make robotic surgery a more economically accessible and better-adapted procedure for an increasing number of procedures. ${ }^{20,21}$ This is why the creation of a robotic surgery program, rather than being a novelty, is a current need for providing our population with stateof-the-art technology that is already a well-established surgical standard today. Ergonomic improvement and surgical results are already well documented in various specialties. ${ }^{22-25}$ Starting a robotic surgery program in our institution has required a radical change in many areas, but over the years it has been carried out satisfactorily. The start of any new program should go hand in hand with low morbidity, low costs and adequate results, ${ }^{26}$ in order to offer the patient a safe program and an adequate transition from conventional open or laparoscopic surgery to this new surgical platform, and thus being able to meet the expectations associated with a new technology, safely and without complications. ${ }^{27,28}$

In the last 250 cases, pancreatic surgery and a larger number of thoracic surgery procedures were introduced. Having surgeons who want to exploit the capabilities of the platform allows the robotic surgery program to grow, with safe procedures and good results in different surgical specialties being offered. Keeping a low level of complications depends on having experienced surgeons who are also aware of the implications of using new surgical equipment. Complications remained stable ( 6 and $6.6 \%$ ) in the first 250 and the second 250 cases during these three years of experience. Robotic surgery offers the great advantage of having a surgical
Table 3. Clavien-Dindo surgical complications classification system

$\begin{array}{ll}\text { Grade } & \text { Definitions } \\ \text { I } & \begin{array}{l}\text { Any deviation from the normal postoperative course } \\ \text { without the need for pharmacological treatment or } \\ \text { surgical, endoscopic and radiological interventions. } \\ \text { Allowed therapeutic regimens are drugs such as } \\ \text { antiemetics, antipyretics, analgesics, diuretics, and } \\ \text { electrolytes and physiotherapy. This grade also } \\ \text { includes wound infections opened at the bedside. }\end{array} \\ \text { II } & \begin{array}{l}\text { Requiring pharmacological treatment with drugs other } \\ \text { than such allowed for grade I complications. Blood } \\ \text { transfusions and total parenteral nutrition are also } \\ \text { included }\end{array} \\ \text { III } & \begin{array}{l}\text { Requiring surgical, endoscopic or radiological } \\ \text { intervention }\end{array} \\ \text { IIIa } & \begin{array}{l}\text { Intervention not under general anesthesia } \\ \text { IIIb }\end{array} \\ \text { IV } & \begin{array}{l}\text { Intervention under general anesthesia } \\ \text { Life-threatening complication (including central } \\ \text { nervous system complications: brain hemorrhage, } \\ \text { ischemic stroke, subarachnoidal bleeding, but } \\ \text { excluding transient ischemic attacks) requiring } \\ \text { intermediate/intensive care unit management }\end{array} \\ \text { IVb } & \begin{array}{l}\text { Single organ dysfunction (including dialysis) } \\ \text { Multi-organ dysfunction }\end{array} \\ & \begin{array}{l}\text { Death of a patient } \\ \text { the suffix "d" (for disability) is added to the respective } \\ \text { degree of complication. This suffix indicates that } \\ \text { follow-up is required to comprehensively evaluate the } \\ \text { complication }\end{array} \\ & \end{array}$

Table 4. Complications according to Clavien classification

\begin{tabular}{|l|l|l|}
\hline Clavien I & 16 & $3.2 \%$ \\
\hline Clavien II & 6 & $1.2 \%$ \\
\hline Clavien IIla & 5 & $1.0 \%$ \\
\hline Clavien IIIb & 6 & $1.2 \%$ \\
\hline
\end{tabular}

simulator within its armamentarium, ${ }^{29}$ which helps both to train new surgeons and to periodically reinforce skills and knowledge of the console. This way, parameters have been established that allow surgeons to remain on constant training, in order for good results with low morbidity in surgical interventions to be ensured.

The increase in the number of robotic surgeons in our institution is a reflection of the interest on this 
Table 5. Comparison between the first 250 cases and all 500 cases

\begin{tabular}{|l|c|c|}
\hline Parameter to be compared & 250 cases & 500 cases \\
\hline HLS & 3.1 días & 2.95 días \\
\hline Surgical time & 4 h $50 \mathrm{~min}$ & 4 h $35 \mathrm{~min}$ \\
\hline Bleeding & $280 \mathrm{ml}$ & $250 \mathrm{ml}$ \\
\hline Complications & $15(6 \%)$ & $33(6.6 \%)$ \\
\hline No. of certified surgeons & 26 & 40 \\
\hline HLS: hospital length of stay. & & \\
\hline
\end{tabular}

HLS: hospital length of stay.

surgical approach, as well as of the need for being able to provide increasingly better procedures to our population. It is essential for high standards in terms of results and training of surgeons to be maintained in order to continue with a successful surgical program. ${ }^{30-32}$ In our institution, the number of certified robotic surgeons increased from 26 to 40 between the first 250 and the second 250 Table $5 .{ }^{33}$ However, there was no statistically significant change in complications, bleeding, surgical time, and hospital length of stay between both these periods.

Urological procedures remain the most commonly performed procedures. However, global statistics have shifted in favor of gynecological surgery. ${ }^{34-37}$

\section{Conclusions}

The robotic surgery program at $A B C$ Medical Center has been shown to be effective from the point of view of results, surgical times and complications, as well as of showing an advance both in the number of cases and in comparative results between initial years and most recent years. The analysis of cases allows evaluating the effectiveness of the program and consolidates the robotic surgery program in our institution as a robust program, with the possibility of involving more specialties and a larger number of physicians.

\section{Conflict of interests}

The authors declare that they have no conflicts of interest.

\section{Funding}

The authors did not receive any sponsoring to carry out this article.

\section{Ethical disclosures}

Protection of human and animal subjects. The authors declare that no experiments were performed on humans or animals for this research.

Confidentiality of data. The authors declare that they have followed the protocols of their work center on the publication of patient data.

Right to privacy and informed consent. The authors declare that no patient data appear in this article.

\section{References}

1. Schuessler WW, Schulam PG, Clayman RV, Kavoussi LR. Laparoscopic radical prostatectomy: initial short-term experience. Urology. 1997; 50(6):854-7.

2. Brinkman W, de Angst I, Schreuder H, Schout B, Draaisma W, Verweij L, et al. Current training on the basics of robotic surgery in the Netherlands: Time for a multidisciplinary approach? Surg Endosc. 2017; 31(1):281-7.

3. Farivar BS, Flannagan M, Leitman IM. General surgery residents' perception of robot-assisted procedures during surgical training. J Surg Educ. 2015;72(2):235-42.

4. Schuessler WW, Schulam PG, Clayman RV, Kavoussi LR. Laparoscopic radical prostatectomy: initial short-term experience. Urology. 1997;50:854-7.

5. Ahlering TE, Woo D, Eichel L, Lee DI, Edwards R, Skarecky DW. Robot-assisted versus open radical prostatectomy: a comparison of one surgeon's outcomes. Urology. 2004;63:819-22.

6. Hu JC, Gu X, Lipsitz SR, Barry MJ, D'Amico AV, Weinberg AC, et al. Comparative effectiveness of minimally invasive vs. open radical prostatectomy. JAMA. 2009;302:1557-664.

7. Coelho RF, Rocco B, Patel MB, Orvieto MA, Chauhan S, Ficarra V, et al. Retropubic, laparoscopic, and robot-assisted radical prostatectomy: a critical review of outcomes reported by high-volume centers. J Endourol. 2010;24(12):2003-15.

8. Lumen N, van Praet C, de Troyer B, Fonteyne V, Oosterlinck W, Decaestecker K, et al. Safe introduction of robot-assisted radical prostatectomy after a training program in a high-volume robotic centre. Urol Int. 2013;91(2):145-52.

9. Moore BW, Dolat ME, McPartlin D, Mayer Grob B, Guruli G, Hampton LJ. Establishment of a new robotic prostatectomy program at a tertiary Veteran's Affairs medical center. J Robot Surg. 2013;7(2):171-5.

10. Gomes MTV, Costa Porto BTD, Parise Filho JP, Vasconcelos AL, Bottura BF, Marques RM. Safety model for the introduction of robotic surgery in gynecology. Rev Bras Ginecol Obstet. 2018;40(7):397-402.

11. Vásquez-Lastra C, Decanini TC, Maffuz-Aziz A, Alfaro AJ, Huante PJ. La cirugía robótica en el Centro Médico ABC: Informe de la formación del comité y la experiencia en los primeros 200 procedimientos realizados. Anales Médicos de la Asociación Médica del Centro Médico ABC. 2018:63(4):312-6.

12. Chan F. Robotic-assisted surgical procedures are the future of gynaecology in Australasia. Aust N Z J Obstet Gynaecol. 2018;58(3):371-4.

13. Nelson B, Kaufman M, Broughton G, Cookson MS, Chang SS, Herrell $\mathrm{SD}$, et al. Comparison of length of hospital stay between radical retropubic prostatectomy and robotic assisted laparoscopic prostatectomy. J Urol. 2007; 177:929-31.

14. Zanagnolo V, Achilarre MT, Maruccio M, Garbi A. Might robotic-assisted surgery become commonplace in endometrial cancer treatment? Expert Rev Anticancer Ther. 2018;18(6):507-9.

15. Kosturakis AK, LaRusso KE, Carroll ND, Nicholl MB. First 100 consecutive robotic inguinal hernia repairs at a Veterans Affairs Hospital. J Robot Surg. 2018;12(4):699-704.

16. Edelman DS. Robotic inguinal hernia repair. Am Surg. 2017;83(12):1418-21.

17. Arcerito M, Changchien E, Bernal O, Konkoly-Thege A, Moon J. Robotic inguinal hernia repair: Technique and early experience. Am Surg. 2016;82(10):1014-7.

18. Mitropoulus D, Atribani W, Graefen M, Remzi M, Roupret M, Truss M. Reporting and grading of complications after urologic surgical procedures: an ad hoc EAU guidelines panel assessment and recommendations. Actas Urol Esp. 2013;37(1):1-11.

19. Tsao AK, Smaldone MD, Averch TD, Jackman SV. Robot-assisted laparoscopic prostatectomy: the first 100 patients-improving patient safety and outcomes. J Endourol. 2009;23:481-4. 
20. Kwon EO, Bautista TC, Blumberg JM, Jung H, Tamaddon K, Aboseif SR et al. Rapid implementation of a robot-assisted prostatectomy program in a large health maintenance organization setting. J Endourol. 2010;24:461-5.

21. Box GN, Ahlering T. Robotic radical prostatectomy: long-term outcomes. Curr Opin Urol. 2008;18:173-9.

22. Yip SKh, Hong SG. Robotic radical prostatectomy in east Asia: development, surgical results, and challenges. Curr Opin Urol. 2010;20(1):80-5.

23. Bolenz C, Gupta A, Hotze T, Ho R, Cadeddu JA, Roehrborn CG, et al. Cost comparison of robotic, laparoscopic, and open radical prostatectomy for prostate cancer. Eur Urol. 2010;57:453-8.

24. Rocco B, Lorusso A, Coelho RF, Palmer KJ, Patel VR. Building a robotic program. Scand J Surg. 2009;98:72-5.

25. Steinberg PL, Merguerian PA, Bihrle W $3^{\text {rd }}$, Seigne JD. The cost of learning robotic-assisted prostatectomy. Urology. 2008:72:1068-72.

26. Longo WE, Cheadle W, Fink A, Kozol R, DePalma R, Rege R, et al. The role of the veterans affairs medical centers in patient care, surgical education, research and faculty development. Am J Surg 2005; 190:662-675

27. Link BA, Nelson R, Josephson DY, Lau C, Wilson TG. Training of urologic oncology fellows does not adversely impact outcomes of robot-assisted laparoscopic prostatectomy. J Endourol. 2009;23:301-5.

28. Tsao AK, Smaldone MD, Averch TD, Jackman SV. Robot-assisted laparoscopic prostatectomy: the first 100 patients-improving patient safety and outcomes. J Endourol. 2009;23(3):481-4.
29. Laviana AA, Hu JC. A comparison of the robotic-assisted versus retropubic radical prostatectomy. Minerva Urol Nefrol. 2013;65(3):161-70.

30. Desai GS. Robotic surgery: is it right for India? J Robot Surg. 2018;12(4):725-6.

31. Lauterbach R, Matanes E, Lowenstein L. Review of robotic surgery in gynecology-The future is here. Rambam Maimonides Med J. 2017; 8(2):e0019.

32. Truong M, Kim JH, Scheib S, Patzkowsky K. Advantages of robotics in benign gynecologic surgery. Curr Opin Obstet Gynecol. 2016;28(4):304-10.

33. Heidenreich A, Bastian PJ, Bellmunt J, Bolla M, Joniau S, van der Kwast $\mathrm{T}$, et al. EAU guidelines on prostate cancer: Part 1-Screening, diagnosis, and treatment of clinically localised disease. Eur Urol. 2011;59:61-71.

34. Trinh QD, Sammon J, Sun M, Ravi P, Ghani KR, Bianchi M, et al. Perioperative outcomes of robot-assisted radical prostatectomy compared with open radical prostatectomy: results from the nationwide inpatient sample. Eur Urol. 2012;61(4):679-85

35. Tewari A, Sooriakumaran P, Bloch DA, Seshadri-Kreaden U, Hebert AE, Wiklund P. Positive surgical margin and perioperative complication rates of primary surgical treatments for prostate cancer: A systematic review and meta-analysis comparing retropubic, laparoscopic, and robotic prostatectomy. Eur Urol. 2012;62:1-15.

36. Gandaglia G, Sammon JD, Chang SL, Choueiri TK, Hu JC, Karakiewicz PI, et al. Comparative effectiveness of robot-assisted and open radical prostatectomy in the postdissemination era. J Clin Oncol. 2014;32(14):216-21. 